\title{
Pengaruh Harga Dan Promosi Terhadap Keputusan Pembelian Konsumen di Toko Nimshop Palu
}

\author{
Sitti Aisya ${ }^{1 *}$ Sarah Eliza2 ${ }^{2}$, Fatma Fatma ${ }^{3}$ Moh. Anwar Zainuddin ${ }^{3}$ \\ ${ }^{1}$ Ekonomi Syariah, Fakultas Ekonomi dan Bisnis Islam, IAIN Palu \\ 2 Ekonomi Syariah, Fakultas Ekonomi dan Bisnis Islam, IAIN Palu \\ ${ }^{3}$ Ekonomi Syariah, Fakultas Ekonomi dan Bisnis Islam, IAIN Palu \\ ${ }^{4}$ Ekonomi Syariah, Fakultas Ekonomi dan Bisnis Islam, IAIN Palu
}

ABSTRAK

Tujuan penelitian ini adalah untuk mengetahui Pengaruh Harga dan Promosi Terhadap Keputusan Pembelian Konsumen di Toko Nimshop Palu. Populasi dalam penelitian ini adalah seluruh pelanggan Nimshop Palu yang berjumlah 75 orang. Teknik pengambilan sampel yang digunakan adalah teknik aksidental sampling.Teknik pengumpulan data melalui teknik observasi dan kuesioner. Kemudian teknik analisa yang digunakan adalah analisis regresi linear berganda. Hasil olahan statistik yang dibantu dengan program SPSS 16 for Windows menunjukan bahwa harga dan promosi secara simultan berpengaruh terhadap keputusan pembelian konsumen di Toko Nimshop Palu. Secara parsial Harga dengan besaran 49,5\% berpengaruh secara signifikan terhadap keputusan pembelian konsumen di Toko Nimshop Palu, dan secara parsial promosidengan besaran 4,73\% berpengaruh secara signifikan terhadap keputusan pembelian konsumen di Toko Nimshop Palu. Nilai koefisien determinasi R2 menunjukan bahwa variabel independen (harga dan promosi) yang diteliti mampu menjelaskan $81,1 \%$ pengaruhnya terhadap variabel dependen (keputusan pembeilan konsumen di Toko Nimshop Palu), sedangkan sisanya 18,9\% yang dijelaskan oleh variabel independen yang lain yang tidak termaksud dalam penelitian ini.
INFORMASI

ARTIKEL

Katakunci:

Harga, promosi, pembelian, konsumen. Toko Nimshp 


\section{Pendahuluan}

Di era globasasi saat ini, tingkat persaingan dunia usaha di Indonesia semakin ketat, karena setiap perusahaan ingin memberikan pelayanan yang terbaik bagi konsumennya. Perusahaan berusaha memenuhi keinginan konsumen yang setiap saat dapat berubah sesuai dengan perkembangan zaman. Kepuasan konsumen merupakan tujuan utama bagi perusahaan.

Salah satu bisnis yang bermunculan saat ini adalah Toko atau Butik yang menjual pakaian atau busana yang sesuai model atau tren saat ini maupun busana yang bernuansa islami. Pakaian atau busana merupakan kebutuhan yang tidak dapat ditinggalkan seseorang dalam kehidupan sehari- hari. Pakaian pada masa ini sudah sangat jauh berbeda fungsinya dengan masa lampau, bila masa lampau pakaian mungkin hanya berfungi sebagai pelindung tubuh dari terik matahari dan cuaca, maka pada saat ini pakaian juga berfungsi sebagai gaya hidup atau biasa disebut dengan life style. Tak dapat dipungkiri, dunia fashion telah mengakarkan pengaruhnya dengan kuat pada kehidupan manusia modern. Dalam menjalankan kebutuhannya, manusia memiliki berbagai macam kebutuhan, baik itu berupa kebutuhan material maupun non material. Dengan adanya kebutuhan tersebut, maka setiap manusia akan berusaha memperoleh dan menggunakan kebutuhan itu sesuai dengan tujuan yang telah ditentukan. Pada dasarnya produk yang ditawarkan adalah untuk memenuhi kebutuhan dan keinginan konsumen. Bagi masyarakat yang beragama islam berbusana muslim bukan hal yang baru lagi karena produk ini sudah lama hadir dan digunakan semua lapisan masyarakat.

Dalam penelitian ini objek yang akan diteliti adalah Toko Nimshop Palu, Toko Nimshop merupakan salah satu penjual produk trend fashion, dalam toko tersebut menjual pakaian wanita di kota Palu yang cukup memiliki banyak pelanggan, terutama pelanggan yang berdominan jenis kelamin perempuan dan mayoritas, yang cenderung selalu ingin memperhatikan penampilan mereka, terutama dari segi busana agar mereka dapat terlihat modis dalam berbagai kesempatan. Konsumen yang rata-rata adalah pelajar dan mahasiswa yang untuk mencukupi kebutuhan sehari-hari masih mengandalkan jatah dari orang tua berusaha untuk semaksimal mungkin dapat memenuhi kebutuhan terutama yang menunjang penampilan mereka.

Menurut Bayley dan Nancarrow perilaku pembelian tidak terencana -tiba didefinisikan sebagai suatu keputusan tiba, persuasif, perilaku pembelian hedonis yang kompleks dimana merupakan suatu proses pengambilan keputusan pembelian yang disebabkan oleh pengaruh stimulus 
Umumnya orang memiliki 1.yang cepat kebiasaan berbelanja untuk memenuhi demikian, sering juga kebutuhan. Meskipun ditemui orang yang berbelanja hanya untuk memenuhi hasrat atau dorongan dari dalam dirinya.

Menurut Sumartono dalam Septila perilaku membeli tidak hanya dilakukan untuk memenuhi kebutuhan melainkan untuk i serta memenuhi hasrat dan konsep dir tuntutan gaya hidup. Penyebab dari kemunculan kondisi seperti ini adalah adanya stimulus lingkungan yang membangkitkan dan mengoptimalkan fungsi hasrat tersebut. Namun terkadang pembelian yang didasari oleh hasrat justru diri sehingga menghilangkan pengendalian terjadinya pembelian yang tidak seharusnya Bahkan dalam beberapa 2.dilakukan wawancara yang dilakukan penulis, ada tiba membeli -sebagian konsumen yang tiba barang hanya karena barang tersebut terlihat mewah, hanya dijual di tempat tersebut, ering dipakai atau dikonsumsi orang, atau $\mathrm{s}$ juga karena terlihat sederhana, meskipun .harga yang ditawarkan cukup mahal

Harga yang ditawarkan Nimshop relatif murah jika dibandingkan dengan harga di toko busana lain. Dikatakan relatif murah jika dibandingkan dengan harga di toko busana lain yang ada di Jl. Tombolotutu karena berbagai produk yang tersedia di Nimshop ditawarkan

1G. Murugananthamdan Ravi Shankar Bhakat, " $A$ Review of Impulse Buying Behavior", International Journal of Marketing Studies 5, no. 3 (2 013): 150, https://www.researchgate.net/publication /280298147 A_Review_of_Impulse_Buying _Behavior/link /55ef157108aedecb68fd96b9/ download di akses 17 agustus 2019.

2ResulikaSeptila,Eka Dian Aprilia“Impulse Buying padaMahasiswadiBanda Aceh", PsikoislamediajurnalPsikologi 2 no. 2 (2017) dalam berbagai mode dan kualitas, sehingga variasi harga sangat beragam.

Dengan kata lain, Nimshop menyediakan berbagai variasi harga . Sistem penetapan harga ini dilakukan untuk mengantisipasi konsumen Nimshop yang kemampuannya dalam hal financial terbatas (terutama kalangan pelajar atau mahasiswa yang notabene uang agar terlihat fashionable). Disamping itu, strategi kebijakan penetapan harga yang dilakukan Nimshop adalah atas dasar persaingan.

Dalam sebulan konsumen yang berbelanja cukup banyak yaitu berjumlah minimal 2500orang konsumen. Jika di hitung rata-rata konsumen yang datang dan melakukan pembelian dalam sehari berjumlah lebih kurang 50-55 orang setiap harinya.

Periklanan adalah kegiatan promosi yang dilakukan oleh pengusaha lewat media yang bertujuan untuk mempengaruhi konsumen agar mereka menjadi kenal produk yang ditawarkan. Berkenaan dengan promosi untuk produknya Nimshop mempromosikannya melalui media sosial seperti Facebook dan Instagram yang semuanya bertujuan untuk menarik minat konsumen untuk berkunjung, melihat-lihat produk yang ditawarkan, setelah melihat-lihat diharapkan konsumen akan tertarik dan selanjutnya memutuskan untuk membeli.

Sebelum konsumen melakukan pembelian,ada faktor yang memengaruhi perilaku konsumen, menurut Kotler perilaku konsumen adalah studi bagaimana tentang individu, kelompok dan organisasi memilih, membeli, menggunakan barang, jasa, ide 
galaman untuk memuaskan atau pen 3.kebutuhan atau keinginan mereka

Memahami perilaku konsumen tentu tidak mudah, karena konsumen mempunyai sifat yang berbeda-beda dalam mengambil keputusan sebagaimana dari kebutuhan manusia yang tidak terbatas disamping dipengaruhi oleh kondisi eksternal dan internal lainnya.Seiring dengan perkembangan selera, pakaian bukanlagi sarana kebutuhan untuk menutupi aurat, namun berperan penting untuk menunjang perfoma seseorang. Banyak tempat yang menjual pakaian dengan varian masing-masing. Mulai dari varian jenis, varian bentuk sampai ke varian merk. Banyaknya pilihan dari yang ditawarkan antar penjual untuk membuat konsumen lebih detail menentukan pilihannya dalam membeli suatu produk.Toko Nimshop berlokasi di jalan Wahid Hasyim no.17 Palu Barat. Produk yang dipasarkan di Toko Nimshop tidak hanya busana muslim, tetapi Toko Nimshop juga menyediakan perlengkapan mukena, kerudung, gamis, blus, rok, sepatu, sendal, tas, dompet aksesoris sebagai penunjang dan lain- lain. Toko Nimshop selalu berusaha menciptakan suasana tempat belanja yang nyaman, lengkap dan harga yang mampu bersaing, selain itu mengutamakan pelayanan yang sopan dan ramah kepada konsumen yang datang. Hal ini dilakukan untuk menguasai pangsa pasar dan meningkatkan omset penjualan.Toko Nimshop selalu berusaha untuk

3Phlip Kotler Dan Kevin Lane Keller, ManajemenPemasaran (Cet. Xiii; Jakarta:

Erlangga, 2009), 166. memenuhi kebutuhan dan keinginan masyarakat (konsumen) yang ingin selalu tampil trendy, up to date dan simple, tanpa meninggalkan tata cara berbusana yang sesuai dengan syar'i.

Keputusan pembelian konsumen merupakan masalah yang sangat kompleks, namun harus tetap menjadi perhatian konsumen. Keputusan pembelian merupakan suatu rangkaian tindakan fisik maupun mental yang dialami konsumen ketika akan melakukan pembelian produk tertentu.4keputusan pembelian sebagai suatu keputusan konsumen yang dipengaruhi oleh ekonomi keuangan, teknologi, politik, budaya, produk, harga, lokasi, promosi, physical evidence (bukti fisik), people (orang)dan process (proses), sehingga membentuk suatu sikap pada konsumen untuk mengelolah segala informasi dan mengambil kesimpulan berupa response (tanggapan) yang muncul pada produk apa yang akan dibeli.5

4Donni Juni Priansa, "Perilaku Konsumen Dalam Persaingan Bisnis Kontemporer",(Bandung: Penerbit Alfabeta, 2017), 88

5

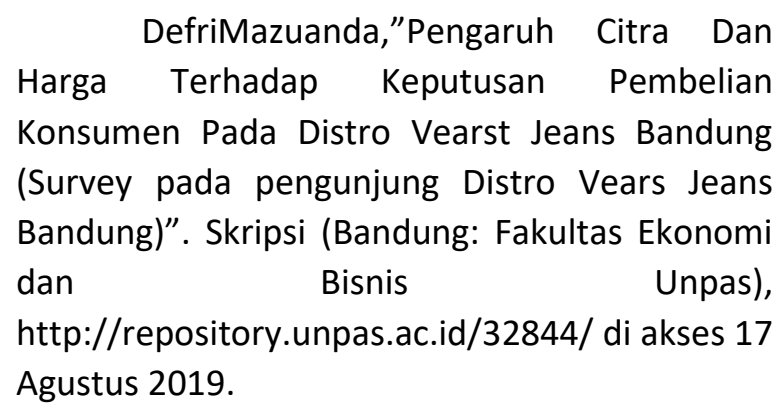
Agustus 2019. 


\section{Tinjauan Pustaka}

\subsection{Kualitas Pelayanan}

\section{Pengertian Harga}

Harga adalah sebuah uang sebagai alat tukar untuk memperoleh produk atau jasa.Harga menurut Kotler \& Armstrong adalah sejumlah uang yang ditagihkan atas suatu produk atau jasa, atau jumlah dari nilai yang ditukarkan para pelanggan untuk memperoleh manfaat dari memiliki atau menggunakan suatu produk atau jasa.

Harga juga dapat diartikan secara sempit maupun secara luas. Menurut Kotler \& Armstrong dalam arti sempit harga adalah jumlah yang ditagihkan atas suatu produk atau jasa. Sedangkan dalam arti luas harga adalah jumlah semua nilai yang diberikan oleh pelanggan untuk mendapatkan keuntungan dari menggunakan suatu produk atau jasa6.

Harga merupakan satu-satunya elemen yang paling menentukan bagi perusahaan untuk mendapatkan pendapatan.Selain itu harga merupakan elemen yang paling fleksibel dalam elemen bauran pemasaran.Harga juga merupakan faktor yang paling penting dan rumit dihadapi oleh para manajer perusahaan.Sehingga penepatan harga merupakan permasalahan yang paling utama yang harus dihadapi oleh para eksekutif.a. Tujuan harga

Tujuan harga menurut Saladin, ada 6 hal yang menjadi tujuan penetapan harga yaitu :

$\begin{array}{lcr}{ }^{6} \text { Apri } & \begin{array}{c}\text { Budianto, } \\ \text { (ed-revisi, }\end{array} & \begin{array}{r}\text { M.M.,Manajemen } \\ \text { Yogyakarta,Penerbit }\end{array} \\ \text { Pemasaran } & \text { Ombak, 2015), 257. }\end{array}$

1) Profit maximalization pricing ( maksimalisasi keuntungan ), yaitu untuk mencapai keuntungan maksmal.

2) Market share pricing( penetapan harga untuk merebut pangsa pasar),. Dengan harga rendah, maka pasar akan dikuasai, syaratnya:

a) Pasar cukup sensitive trhadap harga

b) Biaya produksi dan distribusi turun jika produksi naik

c) Harga turun, pesaing menurun

3) Market skiming pricing. Jika ada kelompok pembeli yang bersedia membayar dengan harga tinggi terhadap produk yang ditawarkan maka perusahaan akan menetapkan harga yang tinngi walaupun kemudian harga tersebut akan turun (memerah pasar) syaratnya7 :

a) Pembeli cukup

b) Perubahan biaya distribusi lebih kecil dari perubahan pendapatan

c) Harga naik tidak begitu berbahaya terhadap pesaing

d) Harga naik menimbulkan kesan produk yang superior

4) Current revenue pricing (penetapan laba untuk pendapatan maksimal). Penetapan harga yang tinggi untuk memperoleh revenue yang cukup agar uang kas cepat kembali.

5) Target profit picing (penetapan harga untuk sasaran). Harga berdasarkan target penjualan pada periode tertentu.

${ }^{7}$ Ibid 259 
6) Promotional pricing( penetapan harga untuk promosi). Penetapan harga untuk suatu produk dengan maksud untuk mendorong penjualan produk-produk lain. Ada dua macam penetapan harga yaitu :

a) Lost leader pricing, yaitu penetapan harga untuk suatu produk agar pasar mendorong penjualan produk yang lainnya.

b) Prestice pricing, yairu penetapan harga yang tinggi untuk suatu produk guna meningkatkan image tentang kualitas.

b. Faktor-faktor penetapan harga

Didalam penetapan harga perlu diperhatikan faktor-faktor yang dapat mempengaruhi, baik langsung maupun tidak langsung. Faktor-faktor yang mempengaruhi secara langsung adalah bahan baku, produksi, biaya pemasaran dan peraturan pemerintah. Sedangkan faktor secara tidak langsung yaitu harga produk sejenis yang dijual oleh para pesaing, pengaruh harga terhadap produk subtitusi dan produk komplementer, potongan serta kredit para penyalur.

Secara garis besar penetapan harga dapat dikelompokkan menjadi empat kategori, yaitu metode penetapan harga yang berbasis permintaan, biaya, laba, dan

persaingan $^{8}$

\section{a. Pengertian promosi}

Promosi adalah arus informasi atau persuasi satu arah yang dapat

\footnotetext{
${ }^{8}$ Fandy Tjiptono” Pemasaran Jasa,Prinsip,Penerapan\&Penelitian,(Yogyakarta,And i 2014), 226.
}

mengarahkan organisasi atau seseorang untuk menciptakan transaksi antara pembeli dan penjual.Promosi merupakan kegiatan terakhir dari marketing mix yang sangat penting karena sekarang ini kebanyakan pasar lebih banyak bersifat pasar pembeli dimana keputusan terakhir terjadinya transaksi jual beli sangat dipengaruhi oleh konsumen.Oleh karena itu pembeli adalah raja.Para produsen berbagai barang bersaing untuk merebut hati para pembeli agar tertarik dan mau membeli barang yang dijual.Kegiatan ini merupakan kegiatan yang termasuk penting selain produk, harga, dan lokasi. ${ }^{9}$

Promosi digunakan untuk menginformasikan kepada orang-orang mengenai produk dan membujuk para pembeli di pasar sasaran sebuah perusahaan, organisasi saluran, dan publik supaya membeli mereknya.Unsur bauran promosi meliputi periklanan, penjualan pribadi, promosi penjualan, dan hubungan masyarakat atau publisitas.Empat unsur bauran promosi tadi biasanya digunakan untuk meningkatkan citra perusahaan terhadap para pesaingnya dan atau menginformasikan, mendidik, dan mempengaruhi sikap dan prilaku beli dari individu, perusahaan, institusi dan atau badan pemerintah yang membentuk sebuah pasar

\footnotetext{
${ }^{9}$ Daryanto, Manajemen Pemasaran, cet. Ke1,
} PT. Sarana Tutorial Nuraini Sejahtera, Bandung. 200 1,94 
sasaran. ${ }^{10}$ Promosi merupakan salah satu variabel dalam bauran pemasaran yang sangat penting dilaksanakan dalam memasarkan produk atau jasa. ${ }^{11}$

Menurut Simamora promosi adalah segala bentuk komunikasi yang digunakan untuk menginformasikan (to inform), membujuk (to persuade), atau mengingatkan orang-orang tentang produk yang dihasilkan organisasi, individu maupun rumah tangga.

b. Indikator Promosi

Menurut Kotler, Indikator yang mencirikan promosi yang digunakan dalam penelitian ini, yaitu :

1. Jangkauan promosi

2. Kuantitas penayangan iklan di media promosi

3. Kualitas penyampaian pesan dalam penayangan iklan di media promosi

4. Potongan harga

c. Tujuan promosi

Tujuan promosi dipilih untuk keseluruhan program promosional dan setiap komponen promosi. Tujuan tertentu, semisal target penjualan dan pangsa pasar, dibagi dengan unsur program pemasaran lainnya. Tujuan promosi meliputi :

1) Menciptakan atau meningkatkan kesadaran pembeli akan produk atau merek.

2) Mempengaruhi sikap para pembeli terhadap sebuah perusahaan, produk atau merek.

\footnotetext{
${ }^{10}$ Henry Simamora, Manajemen Pemasaran Internasional, Jilid II, Rineka Cipta, Jakarta, 2006, 614

${ }^{11}$ Rambat Lupiyoadi, Manajemen Pemasaran Jasa, Salemba Empat, Jakarta, 2001, 108
}

3) Meningkatkan taraf referensi merek dari para pembeli di segmen yang dijadikan sasaran.

4) Mencapai kenaikan penjualan atau pangsa pasar untuk pelanggan spesifik atau calon sasaran.

5) Menghasilkan pembelian ulang sebuah merek.

6) Memikat pelanggan baru. ${ }^{12}$

Keputusan pembelian dalam islam

Keputusan pembelian menurut Nugroho adalah proses pengintogasian yang mengkombinasi sikap pengetahuan untuk mengevaluasi dua atau lebih perilaku alternatif dan memilih salah satu diantaranya. Proses pemindahan kepemilikan dalam perdagangan disebut jual beli yang pada Q.S Al-Baqarah (2):168, sebagai berikut:

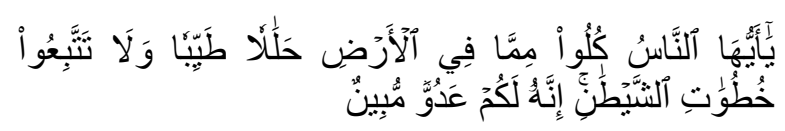

Terjemahnya : "Hai sekalian manusia, makanlah yang halal lagi baik dari apa yang terdapat di bumi, dan janganlah kamu mengikuti langkahlangkah syaitan; karena Sesungguhnya syaitan itu adalah musuh yang nyata bagimu. ${ }^{13}$

\footnotetext{
${ }^{12}$ Henry Simamora, Manajemen Pemasaran Internasional, 618-619

${ }^{13}$ Kementrian Agama Republik Indonesia, Al-Qur'an dan Terjemahannya. (Bandung: PT. Cordoba Internasional, 2012)
}

e-ISSN: $2686-6633$ 
1) Mashlahah dalam Perilaku Konsumen Islami

Syariah Islam menginginkan man usia mencapai dan memelihara kesejahte rannya. Pola konsumsi pada masa kini lebih menekankan aspek pemenuhan keinginan material dari pada aspek kebutuhan yang lain. ${ }^{14}$ Perilaku konsumsi Islami berdasarkan tuntutan Al-Qur'an dan hadis perlu didasarkan atas rasionalitas yang disempurnakan yang mengintegrasikan keyakinan kepada kebenaran yang melampaui rasionalitas manusia yang sangat terbatas ini. ${ }^{15}$

Akibat dari rasionalitas konsumsi yang lebih mendukung individualisme dan Self interest,maka keseimbangan umum tidak dicapai. Yang terjadi adalah munculnya sebagai ketimpangan dalam berbagai persoalan sosial ekonomi. Mencukupi kebutuhan dan bukan memenuhi kepuasan/keinginan adalah tujuan dari aktifitas ekonomi Islam, dan usaha pencapaian itu adalah salah satu kewajiban dalam beragama (mashlahah). ${ }^{16}$

Imam

Al-Ghazali telah membedakan dengan jelas antara keinginan (syahwat) dan kebutuhan (hajat). Kebutuhan adalah keinginan manusia untuk mendapatkan sesuatu yang diperlukan dalam rangka mempertahankan kelangsungan hidupnya dan menjalankan fungsinya.

${ }^{14}$ Mustafa Edwin Nasution, Pengenalan Eksklusif Ekonomi Islam, (Jakarta: Kencana, 2010), ed-1,Cet ke-3.61.

${ }^{15}$ Ibid. 60.

${ }^{16}$ Ibid. 63.
Lebih jauh Imam Al-Ghazali menekankan pentingnya niat dalam melakukan konsumsi sehingga tidak kosong dari makna dan steril. Konsumsi dilakukan rangka beribadah kepada Allah. Pandangan ini tentu sangat berbeda dari dimensi yang melekat pada konsumsi konvensional. Pandangan konvensional yang materialitas melihat bahwa konsumsi merupakan fungsi dari keinginan, nafsu, harga, barang, pendapatan dan lain-lain tanpa memperdulikan pada dimensi spiritual karena hal itu di anggapnya berada diluar wilayah otoritas ilmu ekonomi. ${ }^{17}$

Kehendak seseorang untuk membeli atau memiliki suatu barang/jasa bisa muncul karena faktor kebutuhan ataupun faktor keinginan. Kebutuhan ini terkait dengan segala sesuatu yang harus dipenuhi agar suatu barang berfungsi secara sempurna. Keinginan adalah terkait dengan hasrat atau harapan sesorang yang jika dipenuhi tentu akan meningkatkan kesempurnaan fungsi manusia ataupun suatu barang.

Ajaran Islam tidak melarang manusia untuk memenuhi kebutuhan ataupun keinginannya, selama dengan pemenuhan tersebut, maka martabat manusia bisa meningkat. Semua yang ada di bumi ini diciptakan untuk kepentingan manusia, namun manusia diperintahan untuk mengonsumsi barang/jasa yang halal dan baik saja secara wajar, tidak berlebihan. Pemenuhan kebutuhan ataupun keinginan tetapdibolehkan selama hal

\footnotetext{
${ }^{17}$ Ibid. 70
}

e-ISSN: $2686-6633$ 
itu mampu menambah mashlahah atau tidak mendatangkan mudharat. ${ }^{18}$

Adapun itu Islam tidak menentukan model pakaian tertentu bagi umatnya. Agama menyerahkan sepenuhnya pada manusia untuk berkreasi dalam berpakaian asalkan mengikuti aturan islam. Artinya, meskipun Islam tidak menjelaskan secara detail model pakaian islami, tetapi islam menjelaskan aturan umum dan etika berpakaian yang mesti dipahami dan diamalkan. Dalam islam fungsi utama pakaian adalah menutup aurat sebagaimana tercantum dalam surah al-A'raf (7): 26, sebagai berikut:

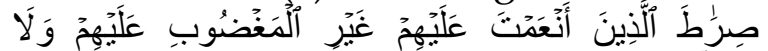

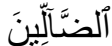

Terjemahnya: "Hai anak Adam, Sesungguhnya kami telah menurunkan kepadamu pakaian untuk menutup aurat dan pakaian indah untuk perhiasan.

Dalam pandangan $\mathrm{KH}$ Ali Mustafa Yaqub, walaupun Islam tidak merekomendasikan satu model pakaian tertentu, tetapi Islam memiliki aturan umum berpakaian.

\section{Metode Penelitian}

Pendekatan yang digunakan dalam penelitian ini adalah pendekatan kuantitaif, karena penelitian ini terfokus untuk mengetahui pengaruh variabel harga dan promosi terhadap keputusan pembelian.

Penelitian ini dilakukan di NIMSHOP PALU yang bertempat di

\footnotetext{
${ }^{18}$ Pusat Pengkajian dan Pengembangan Ekonomi IslamEkonomi Islam/P3EI, (Jakarta: PT. Raja Grafindo Persada), Ed.1, h.130.
}

Jalan Wahid Hasyim no. 17, Kelurahan Baru, Kecamatan Palu Barat, Kota Palu, Provinsi Sulawesi Tengah. Nimshop berdiri sejak tahun 2016. Pengambilan lokasi penelitian di Nimshop, karena Nimshop merupakan salah satu toko yang baru di Kota Palu dengan eksistensi pengunjung yang masih banyak sampai sekarang.

Peneliti memberikan questioner kepada 75 respondent konsumen nasi kuning Puput. Quesioner menggunakan lima skala likert. ${ }^{19},{ }^{20}$

Teknik analisis data yang digunakan dalam penelitian ini adalah analisis kuantitaif, yaitu proses analisis terhadap data-data yang berbentuk angka dengan cara perhitungan secara statistik untuk mengukur pengaruh ketiga variabel tersebut terhadap minat menggunakan keputusan pembelian. an pembelian. $^{21}$ Analisa data dilakukan melalui tahap uni validitas, reabilitas, uji regresi berganda, dan uji asumsi klasik. Untuk oembuktian hipotesis penulis menggunakan uji f dan uji t. ${ }^{22}$

${ }^{19}$ Nurdin, N., Pettalongi, S. S., \& Ahsan, M. N. (2019). Implementation of Teaching Quality Assessment System Using Android. 2019 5th International Conference on Science and Technology (ICST),

${ }^{20}$ Nurdin, N., Pettalongi, S. S., \& Mangasing, M. (2019). Understanding Digital Skill Use from The Technology Continuance Theory (TCT). 2019 6th International Conference on Information Technology, Computer and Electrical Engineering (ICITACEE),

21 Nurdin, N., Musyawarah, I., Nurfitriani, N., \& Jalil, A. (2020). Pengaruh Pelayanan Mobile Banking Terhadap Kepuasan Nasabah (Studi Pada Mahasiswa Perbankan Syariah IAIN Palu) Jurnal Ilmu Perbankan dan Keuangan Syariah, 2(2), 87-104.

${ }^{22}$ Marzuki, M., \& Nurdin, N. (2020). The Influence of Halal Product Expectation, Social e-ISSN: 2686-6633 


\section{Hasil dan Pembahasan}

\subsection{Deskripsi Sample}

Pada bagian metodologi dijelaskan bahwa jumlah sampel yang digunakan dalam penelitian ini adalah 75 orang pelanggan konsumen Nimshop Palu. Data responden dalam penelitian ini dijelaskan dalam tabel sebagai berikut:

Tabel 1

Karakteristik Responden

\begin{tabular}{|c|c|c|c|}
\hline No & $\begin{array}{c}\text { Jenis } \\
\text { Kelamin }\end{array}$ & Jumlah & Presentase \\
\hline 1 & Laki-laki & 5 & $6,6 \%$ \\
\hline 2 & Perempuan & 70 & $93,4 \%$ \\
\hline
\end{tabular}

Pada tabel 1 menunjukkan bahwa dari 75 jumlah sampel dalam penelitian ini yang berjenis kelamin laki-laki berjumlah 5 orang $(6,6 \%)$ dan yang berjenis kelamin perempuan 70 orang $(93,4 \%)$. Sehingga sampel dalam penelitian ini sebagian besar berjenis kelamin perempuan.

\subsection{Hasil Uji Instrumen}

1. Uji Validitas
Uji

mengkorelasikan

Validitas yaitu pernyataan dengan jumlah skor untuk masing-masing variabel. Syarat minimum untuk memenuhi syarat adalah apabila $r=0,3$ jadi apabila kolerasi antar butir dengan skor total

Environment, and Fiqih Knowledge on Intention to Use Shariah Financial Technology Products. International Journal of Innovation, Creativity and Change, 13(1), 171-193. kurang dari 0,3 maka instrumen tersebut tidak valid.23

Tabel 2

Hasil Uji Validitas Instrumen

\begin{tabular}{|c|c|c|c|c|}
\hline Variabel & $\begin{array}{c}\text { Item } \\
\text { Pertan } \\
\text { yaan }\end{array}$ & $\begin{array}{c}\text { Corrected } \\
\text { Item Total } \\
\text { Correlation }\end{array}$ & $\begin{array}{c}\mathrm{R} \\
\text { Kritis }\end{array}$ & Ket \\
\hline Harga & 1 & 0,575 & 0,30 & Valid \\
(X1) & 2 & 0,776 & 0,30 & Valid \\
& 3 & 0,703 & 0,30 & Valid \\
& 4 & 0,687 & 0,30 & Valid \\
& 5 & 0,589 & 0,30 & Valid \\
\hline Promosi & 1 & 0,615 & 0,30 & Valid \\
(X2) & 2 & 0,743 & 0,30 & Valid \\
& 3 & 0,723 & 0,30 & Valid \\
& 4 & 0,579 & 0,30 & Valid \\
Keputusa & 1 & 0,662 & 0,30 & Valid \\
n & 2 & 0,776 & 0,30 & Valid \\
Pembelia & 3 & 0,703 & 0,30 & Valid \\
n & 4 & 0,687 & 0,30 & Valid \\
(Y) & 5 & 0,589 & 0,30 & Valid \\
\hline
\end{tabular}

Sumber: Data: Output SPSS

Pada tabel di atas telihat bahwa nilai $r_{\text {hitung }}$ pad kolom Corrected Item Total Correlation untuk masing-masing dari ke 3 variabel di atas dinyatakan semua pernyataan valid karena $r_{\text {hitung }}$ lebih besar dan positif dari 0,30.

b. Uji Reliabilitas

Melakukan pengujian reliabilitas dalam penelitian ini digunakan program SPSS (Statistical For Sosial Sience) Versi 16 dimana dalam mengukur reliabilitas disini mengunakan uji statistik Cronbach's Alpha (a) lebih dari 0,60.

Hasil pengujian reliabilitas instrumen menggunakan alat bantu oleh

23 Sugiyono, Metode Penelitian Kuantitatif, Kualitatif dan R\&D, (Cet,XXI: Bandung: CV., Alfabeta, 2011), h. 20. 
statistik SPSS versi 16 for windows dapat diketahui sebagaimana tabel berikut.

Tabel 3

Hasil Uji Reliabilitas Instrumen

\begin{tabular}{|l|c|c|c|}
\hline \multicolumn{1}{|c|}{ Variabel } & $\begin{array}{c}\text { Reliability } \\
\text { Coefficiens }\end{array}$ & $\begin{array}{c}\text { Cronbach } \\
\text { Alpha }\end{array}$ & keterangan \\
\hline Harga (X1) & 5 Item & 0,849 & Reliabe1 \\
\hline Promosi (X2) & 5 Item & 0,852 & Reliabe1 \\
\hline $\begin{array}{l}\text { Keputusan } \\
\text { Pembelian (Y) }\end{array}$ & 5 Item & 0,849 & Reliabe1 \\
\hline
\end{tabular}

\subsection{Analisis Regresi Linear Berganda}

Analisis regresi linear berganda adalah salah satu alat statistik nonparametrik yang berfungsi menganalisis keterkaitan dan keterhubungan di antara dua atau lebih variabel penelitian yang berbeda, yaitu variabel dependen dan independen. Dengan membutuhkan data terdiri dari beberapa kelompok hasil observasi pengukuran. Selanjutnya dari hasil analisis regresi berganda ini akan diketahui ada tidaknya pengaruh secara parsial dan simultan variabel Harga (X1), Promosi (X2) dan Keputusan Pembelian (Y).

Berdasarkan hasil olah data meng gunakan SPSS 16 for Windows diperoleh hasil analisis regresi berganda sebagai berikut.

Tabel 4

Hasil Analisis Regresi Linear Berganda

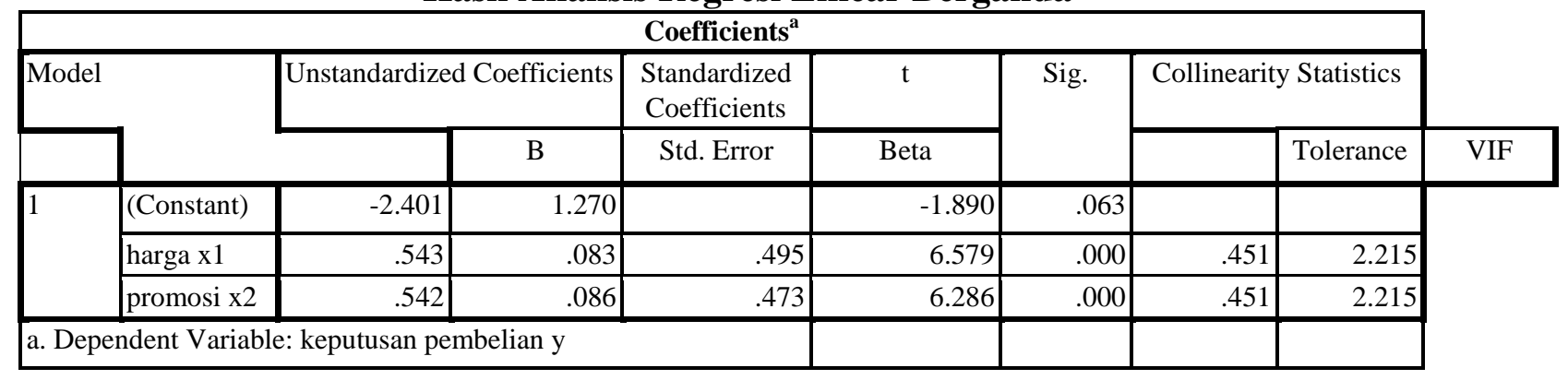

Hasil analisis regresi linear berganda pada tabel diatas, kemudian dimasukkan ke dalam model persamaan regresi berganda sebagai berikut:

$$
\begin{aligned}
& Y=a+b_{1} X_{1}+b_{2} X_{2}+e i \\
& Y=-2.401+0,293 x_{1}+0,357 x_{2}+e i
\end{aligned}
$$

Persamaan regresi linear berganda pada tabel diatas menunjukkan bahwa kedua variabel independen (Harga dan Promosi) memiliki arah positif dan negatif terhadap variabel dependen (Keputusan Pembelian). Hasil perhitungan diatas dapat dijelaskan sebagai berikut: a. Konstanta negatif sebesar $-2,401$ ini berarti jika variabel independen yaitu Harga (X1) dengan besaran 49,5\% dan Promosi (X2) dengan besaran 4,73\% diasumsikan bernilai (0), maka keputusan pembelian meningkat sebesar 0,518\%, sehingga di peroleh kesimpulan ada peningkatan yang terjadi sebesar -2.401 terhadap keputusan pembelian konsumen. maka keputusan pembelian naik sebesar $-2,401$.

b. Koefisien regresi Harga (X1) sebesar 0,543 bernilai positif. Nilai positif $(+)$ pada variabel Harga mempunyai 
makna searah, artinya bahwa setiap terjadinya peningkatan satu variabel Harga (X1) akan meningkatkan keputusan pembelian sebesar 0,543 jika variabel lain dianggap konstan.

c. Koefisien regresi Promosi (X2) sebesar 0,542 bernilai positif. Nilai positif $(+)$ pada variabel Promosi mempunyai makna searah, artinya bahwa setiap terjadinya peningkatan satu satuan variabel Promosi (X2) akan meningkat keputusan pembelian sebesar 0,542 jika variabel lain dianggap konstan.

c. Pembuktian Hipotesis

1. Uji F (Uji Simultan)

Pengujian ini ingin diketahui apakah variabel independen (X) berpengaruh secara bersama-sama memberikan kontribusi secara signifikan terhadap variabel dependen.

Tabel 5

Hasil Uji F (Uji Simultan)

\begin{tabular}{|c|c|c|c|c|c|c|}
\hline \multicolumn{7}{|c|}{ ANOVA $^{b}$} \\
\hline Model & & Sum of Squares & Df & Mean Square & $\mathrm{F}$ & Sig. \\
\hline \multirow[t]{3}{*}{1} & Regression & 950.650 & 2 & 475.325 & 159.552 & $.000^{\mathrm{a}}$ \\
\hline & Residual & 214.496 & 72 & 2.979 & & \\
\hline & Total & 1165.147 & 74 & & & \\
\hline \multicolumn{7}{|c|}{ a. Predictors: (Constant), promosi $\mathrm{x} 2$, harga $\mathrm{x} 1$} \\
\hline De & Variabl & an pembelian & & & & \\
\hline
\end{tabular}

Berdasarkan hasil uji Anova (Analisis Of Varians), atau $\mathrm{F}$ tes diperoleh nilai $F_{\text {hitung }}$ sebesar 159,5> $\quad F_{\text {tabel }} 1,99$ dengan nilai Sig sebesar 0,000 lebih kecil di bandingkan alpha 0,05. Maka dapat diartikan bahwa secara simultan terdapat pengaruh yang signifikan antara variabel Harga (X1) dan Promosi (X2) terhadap Keputusan Pembelian (Y).

Berdasarkan hasil perhitungan statistik uji T dari 2 variabel independen yang dimasukkan dalam model regresi terlihat bahwa:

a. Harga (X1) diperoleh nilai thitung sebesar 6,57> tabel 3,12 dan nilai signifikan (sig) 0,000. Artinya 0,000< 0,05 . Dengan nilai ini memberikan makna bahwa secara parsial variabel Harga (X1) memberikan pengaruh secara signifikan terhadap Keputusan Pembelian (Y). Adapun besaran pengaruhnya dapat dilihat pada kolom Beta. Besaran pengaruh variabel $\mathrm{X} 1$ terhadap variabel $\mathrm{Y}$ yaitu $49,5 \%$.

b. Promisi (X2) diperoleh nilai thitung sebesar 6,28> $t_{\text {tabel }} 3,12$ dan nilai signifikan(sig) 0,000. Artinya $0,000<0,05$. Dengan nilai ini memberikan makna bahwa Promosi (X2) memberikan pengaruh secara signifikan terhadap Keputusan Pembelian (Y). Adapun besaran pengaruhnya dapat dilihat pada kolom Beta. Besaran pengaruh variabel $\mathrm{X} 2$ terhadap varaibel $\mathrm{Y}$ yaitu $4,73 \%$.

\subsection{Pembahasan}

1. Pengaruh Harga dan Promosi Secara Parsial terhadap Keputusan Pembelian Konsumen

Berdasrkan hasil uji statistik di peroleh nilai $t_{\text {hitung }}$ sebesar $6,57>t_{\text {tabel }} 3,12$ 
dan nilai signifikan (sig) 0,000. Artinya $0,000<0,05$. Dengan nilai ini memberikan makna bahwa secara parsial variabel Harga (X1) memberikan pengaruh secara signifikan terhadap Keputusan Pembelian (Y). Adapun besaran pengaruhnya dapat dilihat pada kolom Beta. Besaran pengaruh variabel X1 terhadap variabel $Y$ yaitu $49,5 \%$. Hasil dapat memberikan gambaran bahwa responden (konsumen) memandang bahwa harga yang diberikan sudah mampu mempengaruhi secara signifikan untuk meningkatkan keputusan pembelian.

Berdasarkan hasil uji statistik di peroleh nilai thitung sebesar $6,28>t_{\text {tabel }} 3,12$ dan nilai signifikan (sig) 0,000 . Artinya $0,000<0,05$. Dengan nilai ini memberikan makna bahwa Promosi (X2) memberikan pengaruh secara signifikan terhadap Keputusan pembelian (Y). Adapun besaran pengaruhnya dapat dilihat pada kolom Beta. Besaran pengaruh variabel X2 terhadap varaibel $\mathrm{Y}$ yaitu 4,73\%. Hasil ini dapat memberikan gambaran bahwa reponden (konsumen) memandang bahwa promosi yang dimiliki oleh Nimshop sudah mampu mempengaruhi secara signifikan untuk keputusan pembelian.

2. Pengaruh Harga dan Promosi Secara Simultan terhadap Keputusan Pembelian Konsumen

Hasil pengujian dengan menggunakan analisis regresi berganda dengan

bantuan SPSS 16 for Windows, pengaruh harga dan promosi terhadap keputusan pembelian di Toko Nimshop Palu menunjukkan bahwa secara simultan memiliki pengaruh positif terhadap keputusan pembelian konsumen. Secara parsial variabel Harga dan promosi berpengaruh dan signifikan terhadap Keputusan Pembelian.

Berdasarkan hasil uji Anova analisis data, dengan hasil $F_{\text {hitung }} 159,5>$ $F_{\text {tabel }}$ 1,99 dan memiliki nilai signifikan 0,000 lebih besar di bandingkan dengan alpha 0,05. Dengan demikian hasil ini memberikan makna bahwa variabel Harga (X1) dan Promosi (X2) secara simultan berpengaruh signifikan terhadap keputusan pembelian $(\mathrm{Y})$.

3. Harga dan Promosi terhadap keputusan Pembelian Konsumen dalam Ekonomi Islam

Melihat sejarah dan praktek perdagangan yang diajarkan Rasulullah saw, jelaslah bahwa dalam Islam harga sesungguhnya menjadi bagian yang tidak boleh diintervensi (campur tangan). Hal ini sebagai upaya dalam pembentukkan harga yang adil (qimah al adl) yang sesuai dengan kekuatan permintaan dan penawaran pasar24. Dalam konsep Islam pertemuan antara permintaan dan penawaran tersebut harus sesuai dengan prinsip rela sama rela, tidak ada pihak yang terpaksa dan dirugikan secara dzolim pada tingkat harga tertentu.

Harga merupakan salah satu variabel dari pemasaran atau penjualan. Islam memberikan kebebasan dalam harga yang artinya segala bentuk konsep harga yang terjadi dalam transaksi jual beli diperbolekan dalam ajaran Islam, selama tidak ada adil yang

24 Wibowo Sukarno," Ekonomi Mikro Islam",(Bandung : Pustaka, 2013), h. 211 
melarangnya, dan selama harga tersebut terjadi atas dasar keadilandan suka sama suka antara penjual dan pembeli. Hal ini ditegaskan dalam firman Allah Q.S An-Nisa (4): 29, sebagai berikut:

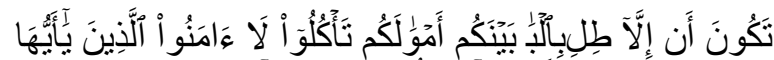

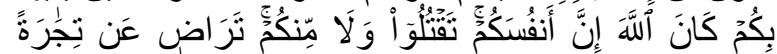
رَجِيمّا

Terjemahnya: "Hai orang-orang yang beriman, janganlah kamu saling memakan harta sesamamu dengan jalan yang batil, kecuali dengan jalan perniagaan yang berlaku dengan suka sama suka diantara kamu, sesungguhnya Allah adalah maha penyayang kepadamu. 25

Ayat diatas menjelaskan bahwa apabila seseorang melakukan jual beli dan tawar

menawar dan tidak ada kesesuaian harga antara penjual dan pembeli, si pembeli boleh memilih akan meneruskan jual beli tersebut atau tidak. Apabila akad (kesepakatan) jual beli telah dilaksanakan dan terjadi pembayaran, kemudian salah satu dari mereka atau keduanya telah meninggalkan tempat akad, keduanya tidak boleh membatalkan jual beli yang telah disepakati.

Ulama fiqh sepakat menyatakan bahwa ketentuan penetapan harga ini tidak dijumpai di dalam Al-Qur'an.

25Kementrian Agama Republik Indonesia, AlQur'an dan Terjemahannya. (Bandung: PT. Cordoba Internasional, 2012)
Adapun dalam hadits Rasulullah saw, dijumpai beberapa riwayat yang menurut logikanya dapat diinduksikan bahwa penetapann harga itu dibolehkan dalam kondisi tertentu. Faktor dominan yang menjadi landasan hukum at-tas'ir al-jabbari, menurut kesepatan para ulama fiqh adalah al-maslahah almursalah (kemaslahatan).26 Anas bin Malik menuturkan bahwa pada masa Rasulullah saw pernah terjadi hargaharga membubung tinggi. Para Sahabat lalu berkata kepada Rasul, "Ya Rasulullah saw tetapkan harga demi kami." Rasulullah saw menjawab:

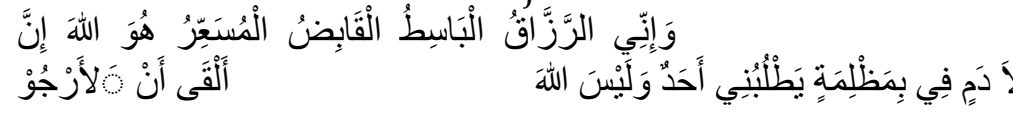

Artinya: "Sesungguhnya Allahlah Zat Yang menetapkan harga, Yang menahan, Yang mengulurkan, dan yang Maha Pemberi rezeki. Sungguh, aku berharap dapat menjumpai Allah tanpa ada seorang pun yang menuntutku atas kezaliman yang aku lakukan dalam masalah darah dan tidak juga dalam masalah harta". (HR Abu Dawud, Ibn Majah dan atTirmidzi). 27

Ulama fiqih menyatakan bahwa kenaikan yang terjadi di zaman Rasulullah saw tersebut bukanlah karena tindakan sewenang-wenang dari para pedagang, tetapi karena memang komoditas yang ada terbatas. Sesuai dengan hukum ekonomi apabila stok

26Setiawan Budi Utomo, Fiqh Aktual (jawaban tuntas maslahah kontemporer). 91

27Imam Hafidz Abu Daud Sulaiman, Sunan Abu Daud. 479 
terbatas, maka wajar barang tersebut naik. Oleh sebab itu, dalam keadaan demikian Rasulullah saw tidak mau campur tangan membatasi harga komoditas tersebut.

Pandangan islam mengenai promosi sudah ada sejak Nabi Muhammad. Nabi Muhammad saw menggunakan promosi dalam perdagangan. Prinsip-prinsip yang digunakan Nabi Muhammad saw berbeda dengan promosi yang dilakukan saat ini. Konsepnya tidak terlepas dari nilai-nilai moralitas dan sesuai dengan etika serta estetika keislaman perdagangan, baik barang maupun jasa.

Promosi dipandang sangat penting dalam dunia perdagangan saat ini dimana persaingan semakin sulit. Akan tetapi meskipun demikian, promosi harus dilakukan sesuai dengan aturan yang ada. Dasar hukum mengenai promosi terdapat dalam Q.S Al-Hujurat ayat (49):6, sebagai berikut:

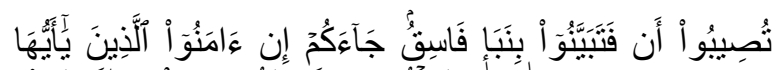

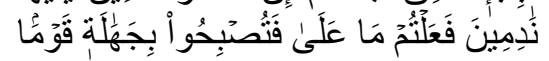

Terjemahnya : "Hai orang-orang yang beriman, jika datang kepadamu orang fasik membawa suatu berita, maka periksalah dengan teliti agar kamu tidak menimpakan suatu musibah kepada suatu kaum tanpa mengetahui keadaannya yang menyebabkan kamu menyesal atas perbuatanmu itu." 28

Maksud ayat diatas adalah bahwa ayat ini termasuk ayat yang mengajarkan adab

dan akhlak yang baik, yaitu keharusan mengklarifikasi akan suatu berita agar tidak

mudah mengikuti kabar berita yang bertanggung jawab. Dan juga tidak mudah menghukumi orang dengan berbekal informasi yang samar dan tidak pastinya kebenarannya.

Keputusan pembelian menurut Nugroho adalah proses pengintogasian yang mengkombinasi sikap pengetahuan untuk mengevaluasi dua atau lebih perilaku alternatif dan memilih salah satu diantaranya. Proses pemindahan kepemilikan dalam perdagangan disebut jual beli yang pada Q.S Al-Baqarah (2):168, sebagai berikut:.

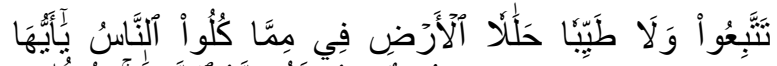

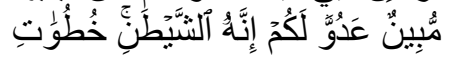

Terjemahnya : "Hai sekalian manusia, makanlah yang halal lagi baik dari apa yang terdapat di bumi, dan janganlah kamu mengikuti langkah-langkah syaitan; karena Sesungguhnya syaitan itu adalah musuh yang nyata bagimu. 29

1. Mashlahah dalam Perilaku Konsumen Islami

28Kementrian Agama Republik Indonesia, AlQur'an dan Terjemahannya. (Bandung: PT.

Cordoba Internasional, 2012)

29Kementrian Agama Republik Indonesia, AlQur'an dan Terjemahannya. (Bandung: PT. Cordoba Internasional, 2012)

e-ISSN: $2686-6633$ 
Syariah Islam menginginkan man usia mencapai dan memelihara kesejahte rannya. Pola konsumsi pada masa kini lebih menekankan aspek pemenuhan keinginan material dari pada aspek kebutuhan yang lain.30 Perilaku konsumsi Islami berdasarkan tuntutan Al-Qur'an dan hadis perlu didasarkan atas rasionalitas yang disempurnakan yang mengintegrasikan keyakinan kepada kebenaran yang melampaui rasionalitas manusia yang sangat terbatas ini.31

Akibat dari rasionalitas konsumsi yang lebih mendukung individualisme dan Self interest,maka keseimbangan umum tidak dicapai.Yang terjadi adalah munculnya sebagai ketimpangan dalam berbagai persoalan sosial ekonomi.Mencukupi kebutuhan dan bukan memenuhi kepuasan/keinginan adalah tujuan dari aktifitas ekonomi Islam, dan usaha pencapaian itu adalah salah satu kewajiban dalam beragama (mashlahah).32

Imam

Al-Ghazali telah

membedakan dengan jelas antara keinginan (syahwat) dan kebutuhan (hajat).Kebutuhan adalah keinginan manusia untuk mendapatkan sesuatu yang diperlukan dalam rangka mempertahankankelangsungan

hidupnya dan menjalankan fungsinya.

Lebih jauh Imam Al-Ghazali menekankan pentingnya niat dalam melakukan konsumsi sehingga tidak kosong dari makna dan steril.Konsumsi dilakukan rangka beribadah kepada

30Mustafa Edwin Nasution, Pengenalan Eksklusif Ekonomi Islam, (Jakarta: Kencana, 2010), ed-1,Cet ke-3. 61.

31Ibid ,60.

32Ibid. 63.
Allah.Pandangan ini tentu sangat berbeda dari dimensi yang melekat pada konsumsi konvensional.Pandangan konvensional yang materialitas melihat bahwa konsumsi merupakan fungsi dari keinginan, nafsu, harga, barang, pendapatan dan lain-lain tanpa memperdulikan pada dimensi spiritual karena hal itu di anggapnya berada diluar wilayah otoritas ilmu ekonomi.33

Kehendak seseorang untuk membeli atau memiliki suatu barang/jasa bisa muncul karena faktor kebutuhan ataupun faktor keinginan.Kebutuhan ini terkait dengan segala sesuatu yang harus dipenuhi agar suatu barang berfungsi secara sempurna. Keinginan adalah terkait dengan hasrat atau harapan sesorang yang jika dipenuhi tentu akan meningkatkan kesempurnaan fungsi manusia ataupun suatu barang.

Ajaran Islam tidak melarang manusia untuk memenuhi kebutuhan ataupun keinginannya, selama dengan pemenuhan tersebut, maka martabat manusia bisa meningkat.Semua yang ada di bumi ini diciptakan untukkepentingan manusia, namun manusia diperintahan untuk mengonsumsi barang/jasa yang halal dan baik saja secara wajar, tidak berlebihan.Pemenuhan kebutuhan ataupun keinginan tetap dibolehkan selama hal itu mampu menambah mashlahah atau tidak mendatangkan mudharat.34

33Ibid. 70

34Pusat Pengkajian dan Pengembangan Ekonomi IslamEkonomi Islam/P3EI, (Jakarta: PT. Raja Grafindo Persada), Ed.1.130.

e-ISSN: $2686-6633$ 


\section{Kesimpulan}

Berdasarkan hasil penelitian dapat disimpulkan bahwa: secara parsial variabel Harga (X1) mempunyai pengaruh signifikan terhadap keputusan pembelian (Y) konsumen di Toko Nimshop Palu, dengan besaran Harga .\%49,5 Dan secara Parsial variabel Promosi (X2) mempunyai pengaruh sig nifikan terhadap keputusan pembelian (Y) konsumen di Toko Nimshop Palu, dengan besaran Promosi 4,73\%

Adapun secara serempak atau simultan variabel Harga (X1) dan Promosi (X2) mempunyai pengaruh signifikan terhadap keputusan pembelian (Y) konsumen di Toko Nimshop Palu, di mana besaran pengaruh dapat dilihat pada tabel summary pada kolom adjusted $R$ square yaitu sebesar $81,1 \%$

Harga dalam Islam pada praktek perdagangan yang diajarkan dalam islam sesunggunya menjadi bagian yang tidak boleh diintervasi (campur tangan), sebagaimana upaya pembentukkan harga yang adil yang sesuai dengan kekuatan permintaan dan penawaran. Dalam konsep islam pertemuan antara permintaan dan penawaran tersebut harus dengan prinsip rela sama rela, tidak ada pihak yang terpaksa dan dirugikan secara dzolim pada tingkat harga. Pandangan islam mengenai promosi sudah ada sejak Nabi Muhammad dalam berdagang. Konsepnya tidak terlepas dari nilai-nilai moralitas dan sesuai dengan etika serta estetika keislaman perdagangan, baik barang maupun jasa. Promosi dipandang sangat penting dalam dunia perdagangan saat ini dimana persaingan sangat sulit. Akan tetapi meskipun demikian, promosi harus dilakukan sesuai dengan aturan yang ada.

\section{Daftar Pustaka}

Anwar, Rosihan, “Pengaruh harga, lokas i dan promosi terhadap keputusa $n$ pembelian (studi pada konsume n Empire Gym)".Skripsi (Bandar Lampung: Universitas Lampung, 2018) http:/ / digilib.unila.ac.id/3 1042/3/SKRIPSI\%20TANPA \% 20 BAB $\%$ 20PEMBAHASAN.pdf, di akses 22 November 2019.

Budianto, Apri, M.M., Manajemen Pemasaran ,ed-revisi, Yogyakarta Penerbit Ombak, 2015

Bungin, Burhan. Metodologi Penelitian Kuantitatif: Komunikasi, Ekonomi Dan Kebijakan Publik Serta IlmuIlmu Sosial Lainnya, Jakarta, Kencana Prenada Media Group, 2009

Daryanto, Manajemen Pemasaran, cet. Ke1, PT. Sarana Tutorial Nuraini

Sejahtera, Bandung,2001

Djaslim Salaadin, Perilaku Konsumen dan Pemasaran Statejik, CV. Linda Karya, Bandung, 2003

Ghozali, Imam, Aplikasi Analisis Muktivariate dengan Program IBM SPSS 21, Semarang: Badan Penerbit Universitas Diponegoro, 2013

Gunawan, Clarisa Monica, Studi Komperatif Pengaruh Tampilan Visual Desain Interior Gerai Coach Terhadap Minat Beli Konsumen Di Surabaya, Jurnak Intra Vol. 5. No. 1, 2017, 44, https://media.neliti.com>publications 
19 Mei 2018

http:/ / eprints.undip.ac.id/29032/1/Skr ipsi021.pdf. Di akses 6 November 2019.Kamaludin, Ahmad, dan Muhammad Alfan. Etika Manajemen Islam, Bandung: CV.Pustaka Setia. 2000

Kotler, Philip Dan Kevin Lane Keller, Manajemen Pemasaran, Cet. Xiii; Jakarta: Erlangga, 2009.

Lupiyoadi, Rambat, Manajemen Pemasaran Jasa, Salemba Empat, Jakarta, 2001

Mazuanda, Defri "Pengaruh Citra Dan Harga Terhadap Keputusan Pembelian Konsumen Pada Distro Vearst Jeans Bandung (Survey pada pengunjung Distro Vears Jeans Bandung)". Skripsi (Bandung: Fakultas Ekonomi dan Bisnis Unpas), http:/ / repository.unpas.ac.id/32 844/ di akses 17 Agustus 2019.

Muhammad, Alimin, Etika dan Perlindungan Konsumen dalam Ekonomi Islam, BPFE, Yogyakarta, 2004.

Muruganantham, G dan Ravi Shankar Bhakat, "A Review of Impulse Buying

Behavior", International Journal of Marketing Studies 5, no. 3 (2013): 1 50, https://www.researchgate.ne t/publication/280298147_A_Revi ew_of_Impulse_Buying_Behavior /link/55ef157108aedecb68fd96b9 /download di akses 17 agustus 2019.

Mustag, Ahmad, The Furture of Economics: An Islamic Perspektif, Asy Syaamil Press \& Grafika, jakarta, 2001

Nasution, Mustafa Edwin, Pengenalan
Eksklusif Ekonomi Islam, Jakarta: Kencana, 2010.

Nurdin, N., Pettalongi, S. S., \& Ahsan, M. N. (2019). Implementation of Teaching Quality Assessment System Using Android. 2019 5th International Conference on Science and Technology (ICST),

Nurdin, N., Pettalongi, S. S., \& Mangasing, M. (2019). Understanding Digital Skill Use from The Technology Continuance Theory (TCT). 2019 6th International Conference on Information Technology, Computer and Electrical Engineering (ICITACEE),

Nurdin, N., Musyawarah, I., Nurfitriani, N., \& Jalil, A. (2020). Pengaruh Pelayanan Mobile Banking Terhadap Kepuasan Nasabah (Studi Pada Mahasiswa Perbankan Syariah IAIN Palu) Jurnal Ilmu Perbankan dan Keuangan Syariah, 2(2), 87-104.

Marzuki, M., \& Nurdin, N. (2020). The Influence of Halal Product Expectation, Social Environment, and Fiqih Knowledge on Intention to Use Shariah Financial Technology Products. International Journal of Innovation, Creativity and Change, 13(1), 171193.

Oci Yonita Marhari, Manajemen Bisnis Modern Ala Nabi Muhammad, AlMaghfiroh, Bandung, 2012.

Philip Kotler, Manajemen Pemasaran, Edisi 12, Diterjemahkan oleh Benyamin Molan, Jilid2, Jakarta: Indeks, 2007.

Philip Khotler, Manajemen Pemasaran Edisi 9, Terjemahan Hendra e-ISSN: $2686-6633$ 
Teguh, PT. Prenhallindo, Jakarta, 2002

Priansa, Donni Juni Priansa, "Perilaku Ko nsumen Dalam Persaingan Bisnis Ko ntemporer", Bandung: Penerbit Alfabeta, 2017.

Priyanto, Dwi, Analisis Korelasi, Regresi, Dan Multivariate Dengan SPSS, Yogyakarta: Penerbit Gava Media, 2013

Pusat Pengkajian dan Pengembangan Ekonomi IslamEkonomi Islam/P3EI, Jakarta: PT. Raja Grafindo Persada.

Qardhawi, Yusuf, Norma dan Etika Bisni Islam, alih Bahasa Zainal Arifin, Jakarta: Gema Insani,1999.

Ratnaningrum, Hesti “Pengaruh

Promisi, harga dan kualitas produk terhadap keputusan pembelian konsumen dalam pembelian bahan bakar minyak jenis

pertalite di kota yogyakarta". Skri psi (Yogyakarta: Universitas Sana ta DharmaYogyakarta, 2016), http s:/ / repository.usd.ac.id/6910/2/ 121324033_full.pdf, di akses 4201 9.

Sarjono, Haryadi Dan Wilda Julianti, SPSS VS LISREL Sebuah Pengantar, Aplikasi Untuk Riset, Jakarta: Salemba Empat, 2011.

Septila, Resulika, Eka Dian Aprilia "Impulse Buying pada Mahasiswa di Banda Aceh", Psikoislamedia jurnal Psikologi 2 no. 2, 2017.

Simamora, Henry, Manajemen Pemasaran Internasional, Jilid II, Rineka Cipta, Jakarta, 2006.

Siregar, Syofyan, Statistika Deskriptif Untuk Penelitian Dilengkapi Perhitungan Manual Dan Aplikasi
SPSS Versi 17, (Ed.1, Cet. 5, Jakarta: Rajawali Pers, 2016

Sudaryono, Metodologi Penelitian, Jakarta:

PT. Raja Grafindo Persada, 2017.

Sujarweni, V.Wiratna, SPSS Untuk Peneli

tian, Yogyakarta: Pustaka Baru Pr ess, 2015

Sukarno, Wibowo," Ekonomi Mikro Islam", Bandung : Pustaka, 2013.

Sunyono, Danang, Analisis Regresi dan

Uji Hipotesis, Yogyakarta: CAPS,2011.

Sunyone, Danang, Dasar-dasar Manajemen Pemasaran, CAPS, Yogyakarta, 2012

Supardi, Metode Penelitian Ekonomi Dan Bisnis, Yogyakarta, UII Perss, 2005.

Tjiptono, Fandy, "PemasaranJasa, Prinsip, Penerapan E Penelitian", Yogyakar ta, Andi 2014.

Wardani, Hetty Sri. "Pengaruh kualitas produk dan harga terhadap minat beli

konsumen muslim pada jaizah Buti que Tlogosari Semarang". Skripsi ( Semarang: Universitas Islam Neger i Walisongo Semarang, 2015), http: //eprints.walisongo.ac.id/5457/1 /112411082.pdf, di akses 11 November 2019. 